Article

\title{
Economic Exposure to Oil Price Shocks and the Fragility of Oil-Exporting Countries
}

\author{
Toon Vandyck*, Alban Kitous, Bert Saveyn, Kimon Keramidas, Luis Rey Los Santos \\ and Krzysztof Wojtowicz
}

European Commission, Joint Research Centre, 41092 Seville, Spain; alban.kitous@ec.europa.eu (A.K.); bert.saveyn@ec.europa.eu (B.S.); kimon.keramidas@ec.europa.eu (K.K.);

luis.rey-los-santos@ec.europa.eu (L.R.L.S.); krzysztof.wojtowicz@ec.europa.eu (K.W.)

* Correspondence: toon.vandyck@ec.europa.eu; Tel.: +34-954488267

Received: 7 March 2018; Accepted: 28 March 2018; Published: 3 April 2018

\begin{abstract}
From a price range between 100 and 120 USD (U.S. dollars) per barrel in 2011-2014, the crude oil price fell from mid-2014 onwards, reaching a level of 26 USD per barrel in January 2016. Here we assess the economic consequences of this strong decrease in the oil price. A retrospective analysis based on data of the past 25 years sheds light on the vulnerability of oil-producing regions to the oil price volatility. Gross domestic product (GDP) and government revenues in many Gulf countries exhibit a strong dependence on oil, while more diversified economies improve resilience to oil price shocks. The lack of a sovereign wealth fund, in combination with limited oil reserves, makes parts of Sub-Saharan Africa particularly vulnerable to sustained periods of low oil prices. Next, we estimate the macroeconomic impacts of a $60 \%$ oil price drop for all regions in the world. A numerical simulation yields a global GDP increase of roughly $1 \%$ and illustrates how the regional impact on GDP relates to oil export dependence. Finally, we reflect on the broader implications (such as migration flows) of macroeconomic responses to oil prices and look ahead to the challenge of structural change in a world committed to limiting global warming.
\end{abstract}

Keywords: oil price volatility; macroeconomic performance; resilience; fragile states; resource curse

\section{Introduction: Making Sense of the Recent Evolution of the Crude Oil Price}

Commodity prices are subject to booms and busts. In the case of crude oil, this is illustrated by the steep decrease in prices between July 2014 and January 2016 (Figure 1). From a price range between 100 and 120 USD (U.S. dollars) per barrel in 2011-2014, Brent crude prices dropped steeply to $26 \mathrm{USD} /$ barrel (bl), the lowest price level observed in nearly 15 years. This price volatility, as well as sustained periods of low oil prices, can bring substantial challenges to those countries that strongly depend on fossil fuel production for jobs and economic growth. The objective of this study is to shed light on the vulnerability of oil-exporting regions with respect to crude oil prices. After a broad discussion of the underlying drivers of the international oil market evolution, the following section presents a backward-looking descriptive analysis into the regional economic dependence on oil production and prices. Next, we assess the macroeconomic impact of a $60 \%$ decrease of crude oil prices. The final section provides a policy discussion and suggestions for future work. 


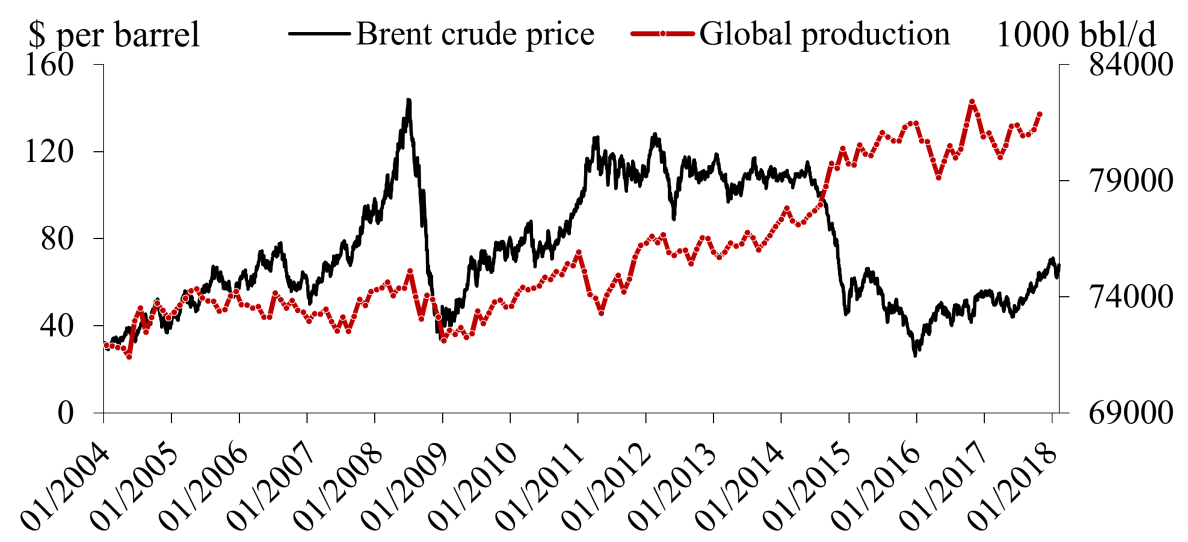

Figure 1. Daily Brent crude oil price (current U.S. dollars, \$) and monthly global production (1000 billion barrels per day, bbl/d). Data source: EIA [1]. Latest price data point: 26 February 2018.

When seen in a long-run context, the oil price coming down from high levels in 2011-2013 may not be a surprise to those claiming the end of a commodity supercycle [2]. Nevertheless, various underlying drivers have been suggested to explain the sharp price decline [3-7]. Common across most studies is the finding that the oil price drop resulted from several factors occurring simultaneously.

First, unanticipated changes in crude oil production can generally explain an important part of oil price fluctuations in the short term. The rise of tight oil, often labelled shale oil, in the United States could have put downward pressure on the international oil price. The production of oil from unconventional sources has led to a strong increase in U.S. oil output from 2011 onwards. Consequently, the U.S. oil production volumes became the largest in the world, exceeding those of Russia and Saudi Arabia. Perhaps in response, the Organization of Petroleum Exporting Countries decided in late 2014 not to reduce production levels despite the low prices. Saudi Arabia's shift from the role of "swing producer" to a strategy focused on market share can have important implications on price stability, and has likely contributed substantially to the observed oil price drop. Although analysts expected that unconventional oil production in the U.S. would fall swiftly when oil prices dropped below breakeven points, in the reality the response was more sluggish and less elastic, further contributing to the oversupply of the market [8]. Furthermore, production levels in Iraq and Libya were higher than expected. A second factor that can contribute to a drop in oil prices is a decline in (expected) oil consumption. A period of more than 10 years of double-digit annual GDP growth rates came to an end in 2014 in China, which has become the second largest consumer of oil in the world after the U.S. With the GDP in 2016 only 1.2\% higher than the previous year, anticipations for long-run growth may have been revised, with corresponding consequences for oil demand expectations in Asia putting downward pressure on the price. Furthermore, energy and climate policies in regions such as Europe are favoring a more efficient use of (low-carbon) energy, lowering future oil consumption. From February 2015 onwards, countries submitted climate pledges labelled Intended Nationally Determined Contributions to the United Nations Framework Convention on Climate Change, eventually leading to the Paris Agreement in December 2015. This landmark agreement sends a signal of global willingness to address the challenge of climate change, and move onto a pathway of sustainable growth in which the share of fossil fuels in total primary energy consumption plays a smaller role than is the case today. Another factor affecting oil demand is technological change, particularly in the transportation sector. Although liquid biofuel covered only around $2 \%$ of world liquid fuel consumption [9] and the electric vehicle penetration rate in total sales was limited to $0.5 \%$ in $2015[10,11]$, the cost decrease of batteries observed in recent years may shift the expectations of the electrification of the vehicle fleet in the medium to long term. Third, the relative dynamics of supply and demand resulted in remarkably positive stock changes in 2014-2015 (nearly 1 million barrels per day (Mbl/d) in 2014 and $2 \mathrm{Mbl} / \mathrm{d}$ in 2015 [9]), sending a strong signal of an abundantly supplied oil 
market and perhaps marking the end of a supercycle, in which demand cannot sufficiently adjust to a rapidly rising demand. Fourth, changes in the U.S. dollar exchange rate may lead to oil price fluctuations, as the U.S. dollar is the main currency for the global oil trade. The appreciation of the U.S. dollar makes crude oil more expensive for the rest of the world, reducing oil demand and leading to lower oil prices expressed in U.S. dollars.

Can we derive useful insights for the future evolution of the oil price? The price levels observed in 2015-2017 may be insufficient to sustain production levels for some sources (Figure 2). This in turn can reduce the oversupply, tighten the market, and raise prices, although the adjustment time lag is uncertain. Low oil price levels affect regions and sources with high extraction and production costs at the margin. In Europe, the North Sea may be an area that is affected by low oil prices, with the break-even price for many fields around 60 USD. In North America, relatively high-cost unconventional oil projects may become unprofitable at low oil price levels. Most oil exporters from the Middle-East and Africa have marginal production costs lower than the current oil price (Figure 2), which implies that their production level should only be marginally affected if the price is not decreasing further. On the oil demand side, a low price level could limit the incentives for investing in energy efficiency improvements as well as for developing alternatives to oil. The estimated share of electricity in total energy consumption in the transport sector ranges from $1 \%$ by 2035 [12] to $6-10 \%$ in 2050 [13], depending on climate policies. The five-yearly pledge-and-review cycles included in the Paris Agreement will provide an indication as to where global climate change mitigation ambitions are headed. Decisions of large countries such as India to ratchet up climate action, or to step out of the agreement such as the U.S., can have an impact on oil demand expectations and price levels. An alternative way to look ahead to the short-run evolution of the oil price is to evaluate the futures market, although they do not necessarily provide a good long-term forecast [14]. An outlook [15] estimated that Brent crude oil would average 34 U.S. dollar per barrel (USD/bl) in 2016 and 40 USD/bl in 2017, slightly below the price in the futures market, while actual prices were around $44 \mathrm{USD} / \mathrm{bl}$ and 54 USD/bl in 2016 and 2017, respectively. A different study [4] states that oil prices are likely to remain low over the medium term, and could range between $60 \mathrm{USD} / \mathrm{bl}$ and $70 \mathrm{USD} / \mathrm{bl}$ in the long term. Projections show [16,17] that Brent crude oil would range between $100 \mathrm{USD} / \mathrm{bl}$ and $150 \mathrm{USD} / \mathrm{bl}$ in 2030 (expressed in the value of the USD in 2014), and highlight the role of international climate policies on the oil price.

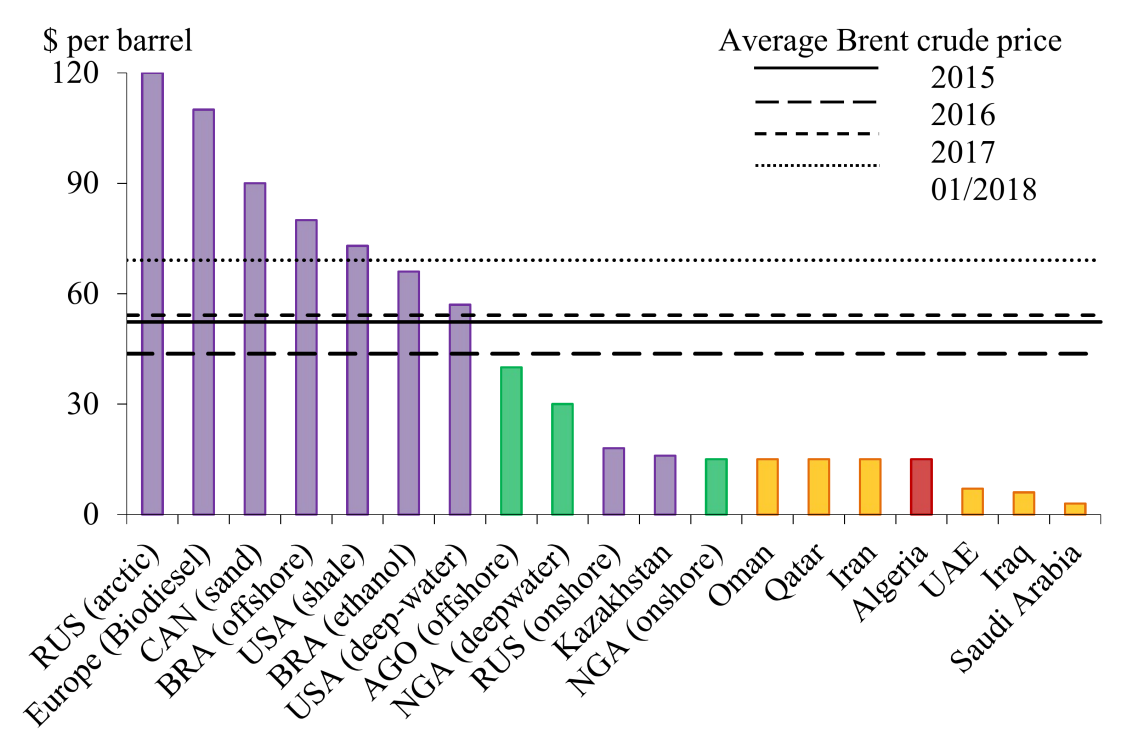

Figure 2. Marginal production costs (2014) vs. Brent price in \$ (U.S. dollars, USD). Data source: [1,18]. Abbreviations: Russia (RUS), Canada (CAN), Brazil (BRA), Angola (AGO), Nigeria (NGA) and United Arab Emirates (UAE). 


\section{Retrospective Analysis of the Exposure to the Global Oil Market}

This part of the paper starts off with a set of descriptive statistics that highlights the weight of oil-producing countries in the export market and their political stability, human development, and economic structure. Furthermore, Section 2.1 discusses the availability and size of a sovereign wealth fund that may serve to absorb oil price shocks. Combined, these statistics provide a first indication of a broad-based resilience to cope with short-run oil market disruptions. The next step in the analysis is a backward-looking assessment of macroeconomic exposure to oil price fluctuations. The estimations presented in Section 2.2 reveal the sensitivity of GDP and government revenues to the oil price over the period of 1990-2014.

\subsection{Exploring the Vulnerability of Oil Exporters to Low Oil Prices}

The internationally traded crude oil (in 2014) is supplied by the countries listed in Table 1. Combined, the crude oil production volumes of these countries covered roughly $70 \%$ of the world output in 2014 [19], of which of which more than one-third is supplied by only two countries: Saudi Arabia (19\% of exports) and Russia (17\%). The geographic location and the regional aggregation (color scheme used throughout the paper) is shown in Figure 3. The remainder of this paper focuses on a subset of oil-exporting countries that excludes Turkmenistan, Brunei, Colombia, Ecuador, and Trinidad \& Tobago.

Table 1. Descriptive statistics for oil-exporting countries (2014). Data source: Oil production and consumption [19,20]; population [21]. Abbreviations: Commonwealth of Independent States (CIS).

\begin{tabular}{|c|c|c|c|c|c|c|}
\hline Country & Code & Region & $\begin{array}{l}\% \text { of Net } \\
\text { Exports }\end{array}$ & $\begin{array}{c}\% \text { of } \\
\text { Production }\end{array}$ & $\begin{array}{c}\text { Reserves } \\
\left(10^{9} \text { Barrels }\right)\end{array}$ & $\begin{array}{c}\text { Population } \\
\text { (Million) }\end{array}$ \\
\hline Saudi Arabia & SAU & Middle-East & $19.0 \%$ & $13.0 \%$ & 267 & 31 \\
\hline United Arab Emirates & ARE & Middle-East & $6.5 \%$ & $4.2 \%$ & 98 & 9 \\
\hline Kuwait & KWT & Middle-East & $6.0 \%$ & $3.5 \%$ & 102 & 4 \\
\hline Iraq & IRQ & Middle-East & $5.7 \%$ & $3.7 \%$ & 150 & 35 \\
\hline Qatar & QAT & Middle-East & $3.8 \%$ & $2.2 \%$ & 26 & 2 \\
\hline Iran & IRN & Middle-East & $3.6 \%$ & $4.1 \%$ & 158 & 78 \\
\hline Oman & $\mathrm{OMN}$ & Middle-East & $1.9 \%$ & $1.1 \%$ & 5 & 4 \\
\hline Algeria & DZA & North Africa & $2.6 \%$ & $1.7 \%$ & 12 & 39 \\
\hline Libya & LBY & North Africa & $0.5 \%$ & $0.6 \%$ & 48 & 6 \\
\hline Nigeria & NGA & Sub-Saharan Africa & $4.9 \%$ & $2.7 \%$ & 37 & 177 \\
\hline Angola & AGO & Sub-Saharan Africa & $3.6 \%$ & $1.9 \%$ & 13 & 24 \\
\hline Equatorial Guinea & GNQ & Sub-Saharan Africa & $0.6 \%$ & $0.3 \%$ & 1 & 1 \\
\hline Republic of Congo & COG & Sub-Saharan Africa & $0.6 \%$ & $0.3 \%$ & 2 & 5 \\
\hline Gabon & GAB & Sub-Saharan Africa & $0.5 \%$ & $0.3 \%$ & 2 & 2 \\
\hline Sudan * & SDN & Sub-Saharan Africa & $0.3 \%$ & $0.2 \%$ & 5 & 51 \\
\hline Chad & TCD & Sub-Saharan Africa & $0.2 \%$ & $0.1 \%$ & 2 & 14 \\
\hline Russia & RUS & Other: CIS & $17.4 \%$ & $12.2 \%$ & 103 & 143 \\
\hline Kazakhstan & KAZ & Other: CIS & $3.3 \%$ & $1.9 \%$ & 30 & 17 \\
\hline Azerbaijan & $\mathrm{AZE}$ & Other: CIS & $1.7 \%$ & $1.0 \%$ & 7 & 10 \\
\hline Turkmenistan ** & TKM & Other: CIS & $0.2 \%$ & $0.3 \%$ & 1 & 5 \\
\hline Brunei ${ }^{* *}$ & $\mathrm{BRN}$ & Other: Asia & $0.3 \%$ & $0.1 \%$ & 1 & 0.4 \\
\hline Venezuela & VEN & Other: Americas & $4.3 \%$ & $3.1 \%$ & 298 & 31 \\
\hline Canada & CAN & Other: Americas & $4.4 \%$ & $4.8 \%$ & 173 & 36 \\
\hline Mexico & MEX & Other: Americas & $1.9 \%$ & $3.1 \%$ & 11 & 125 \\
\hline Colombia ** & COL & Other: Americas & $1.6 \%$ & $1.1 \%$ & 2 & 48 \\
\hline Ecuador $* *$ & ECU & Other: Americas & $0.7 \%$ & $0.6 \%$ & 8 & 16 \\
\hline Trinidad \& Tobago ** & TTO & Other: Americas & $0.2 \%$ & $0.1 \%$ & 1 & 1 \\
\hline Norway & NOR & Other: Europe & $3.8 \%$ & $2.1 \%$ & 7 & 5 \\
\hline
\end{tabular}

* Includes both Sudan and South Sudan; ${ }^{* *}$ not included in the following graphs for the sake of clarity. 


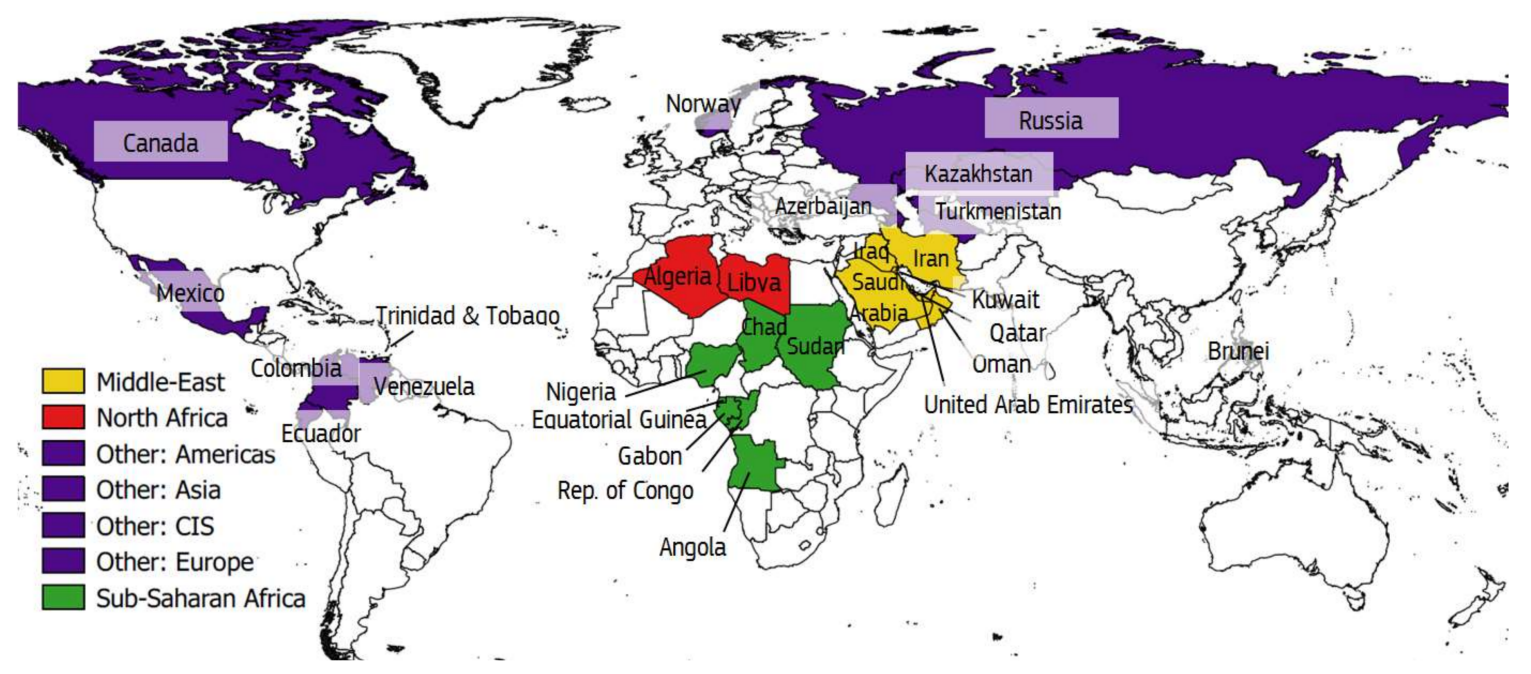

Figure 3. Map of oil exporting countries (2014).

Figure 4 displays the political stability index [22] of oil exporters as a function of their human development index (HDI, [23]). The political stability index aims to measure the perceptions of political stability in a country, including the likelihood of politically motivated violence, while the human development index captures aspects such as health, education, and living standards.

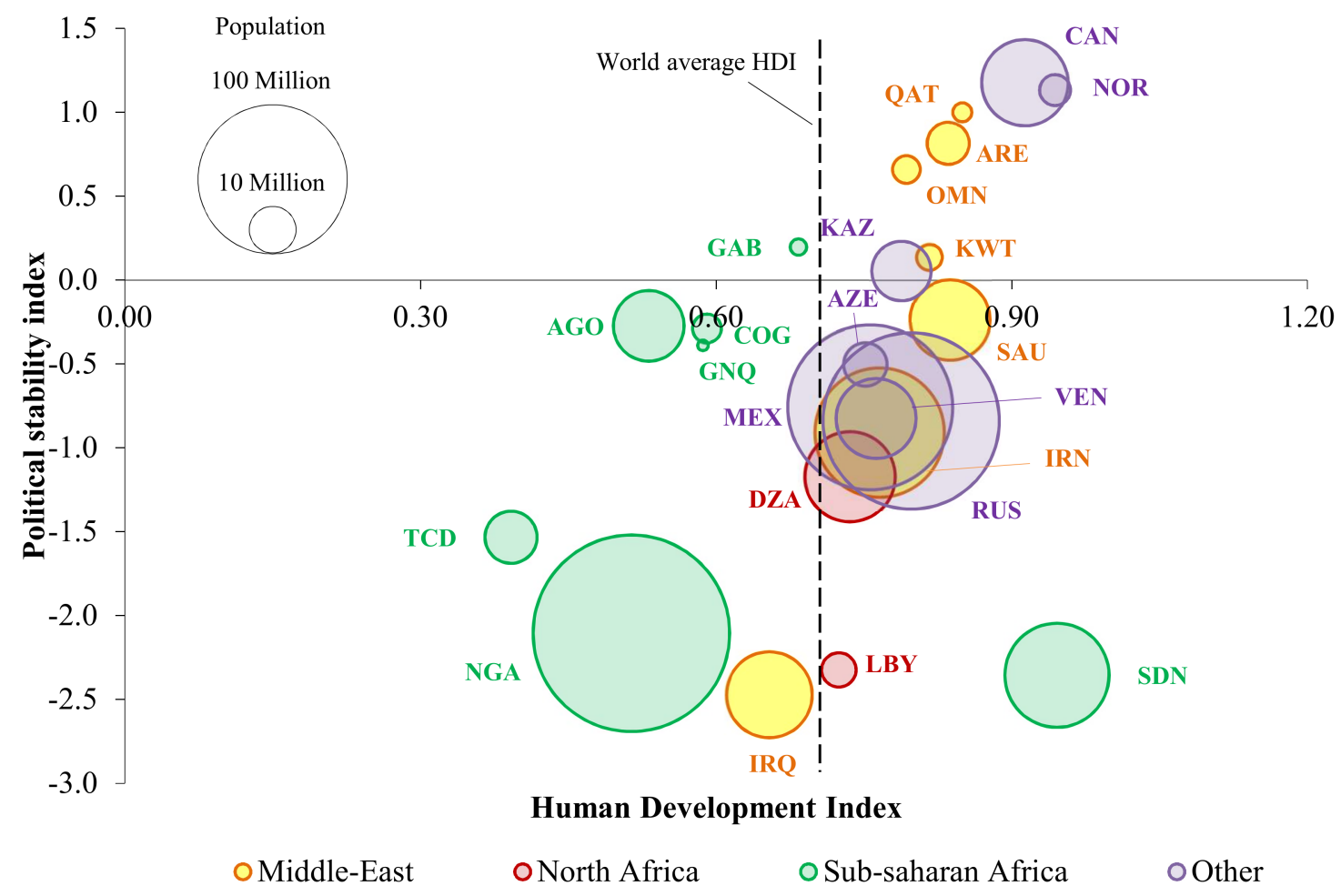

Figure 4. Political stability and human development index (HDI) for oil exporting countries (2014). Data source: political stability indicator [22], HDI [23]. Size of the bubble indicates population size in 2014 [21]. 
Most Sub-Saharan African producers score relatively low on political stability, with the exception of Gabon (GAB), a small producer with a small population. Nigeria (NGA), in particular, appears as a large (highest and fast-growing population, with close to 180 million inhabitants in 2014) and a socioeconomically fragile country. In addition, some important North African and Middle Eastern exporters also display a low political stability: Algeria (DZA) and Iran (IRN) in addition to Iraq (IRQ) and Libya (LBY), which is currently undergoing violent conflicts. Other important exporters, such as Saudi Arabia (SAU) and the other Gulf Cooperation Council (GCC) countries (Bahrain, Kuwait, Oman, Qatar, Saudi Arabia, and the United Arab Emirates) are perceived to have a higher stability. Norway (NOR) and Canada (CAN) appear rather stable, while other non-OECD exporters present a contrasted situation, with Mexico (MEX), Russia (RUS), and other CIS (Commonwealth of Independent States: the former Soviet Republic except the Baltic States) countries scoring in-between Iran and Saudi Arabia.

For a more comprehensive analysis on the capacity of states to cope with a low oil price, Table 2 complements the abovementioned statistics with numbers on oil-related sovereign wealth funds (SWF) that may be used as a buffer capacity with a quicker response time than putting oil reserves into production. Interestingly, all Middle Eastern exporters have a SWF: while Iraq's SWF is small and Oman and Iran have limited funds with respect to GDP (still 100\% of government revenues in the case of Iran), other exporters have important funds ranging from 85\% of GDP (Saudi Arabia; twice the size of the government revenues) to more than $300 \%$ of GDP (Kuwait and the United Arab Emirates). Saudi Arabia announced in April 2016 its intention to expand its second largest sovereign wealth fund, the Public Investment Fund (PIF), to nearly 2 trillion USD by 2030, which would add up to a total of 2.5 trillion USD if the other funds remain at the same level as of today. Furthermore, North African oil exporters have more substantial funds, with Algeria at $23 \%$ of total GDP (70\% of government revenues) and Libya at $160 \%$ of GDP. Importantly, Sub-Saharan African oil exporters have not established a SWF (Congo, Gabon, Sudan, and Chad) or only up to limited amounts (Nigeria and Angola). The lack of a SWF as an adjustment mechanism renders these countries more vulnerable to short term oil price shocks.

Table 2. Oil-related sovereign wealth funds (SWFs) (2014). Data sources: Oil-related SWFs [24], population [21], GDP [25], government revenue [26]. SWFs taken into account: ARE (ADIA, ICD, ADIC, IPIC, MDC, EIA, RIA); SAU (SAMA, PIF); KWT (KIA); QAT (QIA); IRN (NDF); OMN (OIF); IRQ (DFI); LBY (LIA); DZA (RRF); AGO (FSDEA); NGA (BDIC, NSIA); RUS (RNWF, RRF, RDIF); KAZ (S-K JSC, KNF, NIC); AZE (SOFAZ); CAN (AHSTF); MEX (ORSFM, FMP); VEN (FEM); NOR (GPF).

\begin{tabular}{|c|c|c|c|c|c|c|}
\hline Country & Code & Region & $\begin{array}{c}\text { Value } \\
\text { (Billion USD) }\end{array}$ & $\begin{array}{l}\text { Per Capita } \\
\text { (1000 USD) }\end{array}$ & $\%$ GDP & $\begin{array}{c}\text { \% Government } \\
\text { Revenue }\end{array}$ \\
\hline United Arab Emirates & ARE & Middle-East & 1214 & 134 & $304 \%$ & $805 \%$ \\
\hline Saudi Arabia & SAU & Middle-East & 792 & 26 & $106 \%$ & $284 \%$ \\
\hline Kuwait & KWT & Middle-East & 592 & 158 & $362 \%$ & $527 \%$ \\
\hline Qatar & QAT & Middle-East & 256 & 118 & $122 \%$ & $257 \%$ \\
\hline Iran & IRN & Middle-East & 62 & 1 & $15 \%$ & $100 \%$ \\
\hline Oman & $\mathrm{OMN}$ & Middle-East & 40 & 9 & $49 \%$ & $103 \%$ \\
\hline Iraq & IRQ & Middle-East & 1 & 0 & $0 \%$ & $1 \%$ \\
\hline Libya & LBY & North Africa & 66 & 11 & $160 \%$ & $392 \%$ \\
\hline Algeria & DZA & North Africa & 50 & 1 & $23 \%$ & $70 \%$ \\
\hline Angola & AGO & Sub-Saharan Africa & 5 & 0 & $4 \%$ & $10 \%$ \\
\hline Nigeria & NGA & Sub-Saharan Africa & 1 & 0 & $0 \%$ & $2 \%$ \\
\hline Russia & RUS & Other: CIS & 139 & 1 & $7 \%$ & $20 \%$ \\
\hline Kazakhstan & KAZ & Other: CIS & 79 & 5 & $36 \%$ & $149 \%$ \\
\hline Azerbaijan & $\mathrm{AZE}$ & Other: CIS & 37 & 4 & $50 \%$ & $128 \%$ \\
\hline Canada & CAN & Other: Americas & 18 & 0 & $1 \%$ & $3 \%$ \\
\hline Mexico & MEX & Other: Americas & 6 & 0 & $0 \%$ & $2 \%$ \\
\hline Venezuela & VEN & Other: Americas & 1 & 0 & $0 \%$ & $1 \%$ \\
\hline Norway & NOR & Other: Europe & 848 & 165 & $170 \%$ & $316 \%$ \\
\hline
\end{tabular}

Note: oil exporters without SWF are not shown in the table: Republic of Congo, Gabon, Sudan, and Chad. 
To further identify the oil-exporting countries that are most vulnerable to economic and social upheaval due to a long period of low oil prices, the following figures highlight the role of oil in the economy and as a source of government revenue. Figures 5 and 6 show the relation between oil reserves per capita and oil exports, the latter expressed in value relative to GDP (Figure 5) or government revenue (Figure 6) in the year 2014. Oil exports are calculated as the product of oil exports in volume (production minus consumption) by the oil price (Brent, in current USD) and divided by GDP or government revenue (in current USD at Market Exchange Rate, MER). Expressing oil exports relative to GDP indicates the overall economy-wide importance, while comparing against government revenue serves as a proxy to evaluate the potential importance of the oil sector for the state budget, even though it does not show explicitly the direct government revenue from the oil sector. Norway (NOR) is shown as a reference point because it has the highest income per capita, the highest human development index, and with Canada, the highest political stability of all oil exporters, as shown in Figure 4.

Four groups of countries can be identified based on Figures 5 and 6 (relative to Norway (NOR)):

- Upper left: high exposure of the economy and government revenue and limited reserves per capita. This is especially true for Congo (COG), Angola (AGO), Gabon (GAB), and Azerbaijan (AZE), and to a lesser extent for Russia (RUS) and Algeria (DZA). In Nigeria (NGA), the most populated of all exporters, oil exports are larger than the government revenues, indicating that resources for the government are potentially much more exposed to the oil market than when looking only at GDP. When looking at oil exports relative to government revenue, a regional pattern emerges with many Sub-Saharan African countries located in the top left part of Figure 6, suggesting particular vulnerability to oil prices in the region.

- Upper right: high exposure of the economy and government revenue, but high reserves that can act as a long-term buffer for the economy. This group gathers most of the Middle-Eastern exporters. Oil exports are in particular very high compared to GDP for Iraq (IRQ) and Saudi Arabia (SAU), even though their high reserves per capita may give some longer-term resilience to oil price changes. The value of oil exports nearly matches the size of government revenues in Iran (IRN), hinting at a strong relation between the state's fiscal capacity and the oil price. The conflict in Libya (LBY), a country with very high reserves per capita that is shown in this category, has origins that go beyond the oil market. With high reserves per capita, Venezuela (VEN) also features in this group, with more favorable conditions with respect to exposure and resource availability (including nonconventional oil), although the country is facing an economic downturn as of recently. The latter two examples highlight that oil markets are not the only determinant of political and economic stability.

- Lower left: limited reserves but limited exposure of the economy. This group actually gathers only Mexico (MEX) and Sudan (SDN), two large countries where oil exports are small, making their economies comparably less dependent on the oil market.

- Lower right: high reserves and low exposure of the economy. This is the group with the expected highest economic stability with respect to oil price: small oil exports compared to GDP and high reserves per capita. In this group we find Canada (CAN), which does not come as a surprise based on the high political stability and human development statistics displayed in Figure 4. 




\section{Reserves per capita (1000 barrels)}

o Other oMiddle-East oSub-saharan Africa oNorth Africa

Figure 5. Exposure of economy: oil exports vs. GDP (2014). Note: The blue dotted lines are centered on Norway (NOR). Data: $[19,21,25]$. Kuwait (KWT) is not shown because it has very high reserves per capita $(27,000 \mathrm{bl}$, oil exports $\sim 60 \% \mathrm{GDP})$.

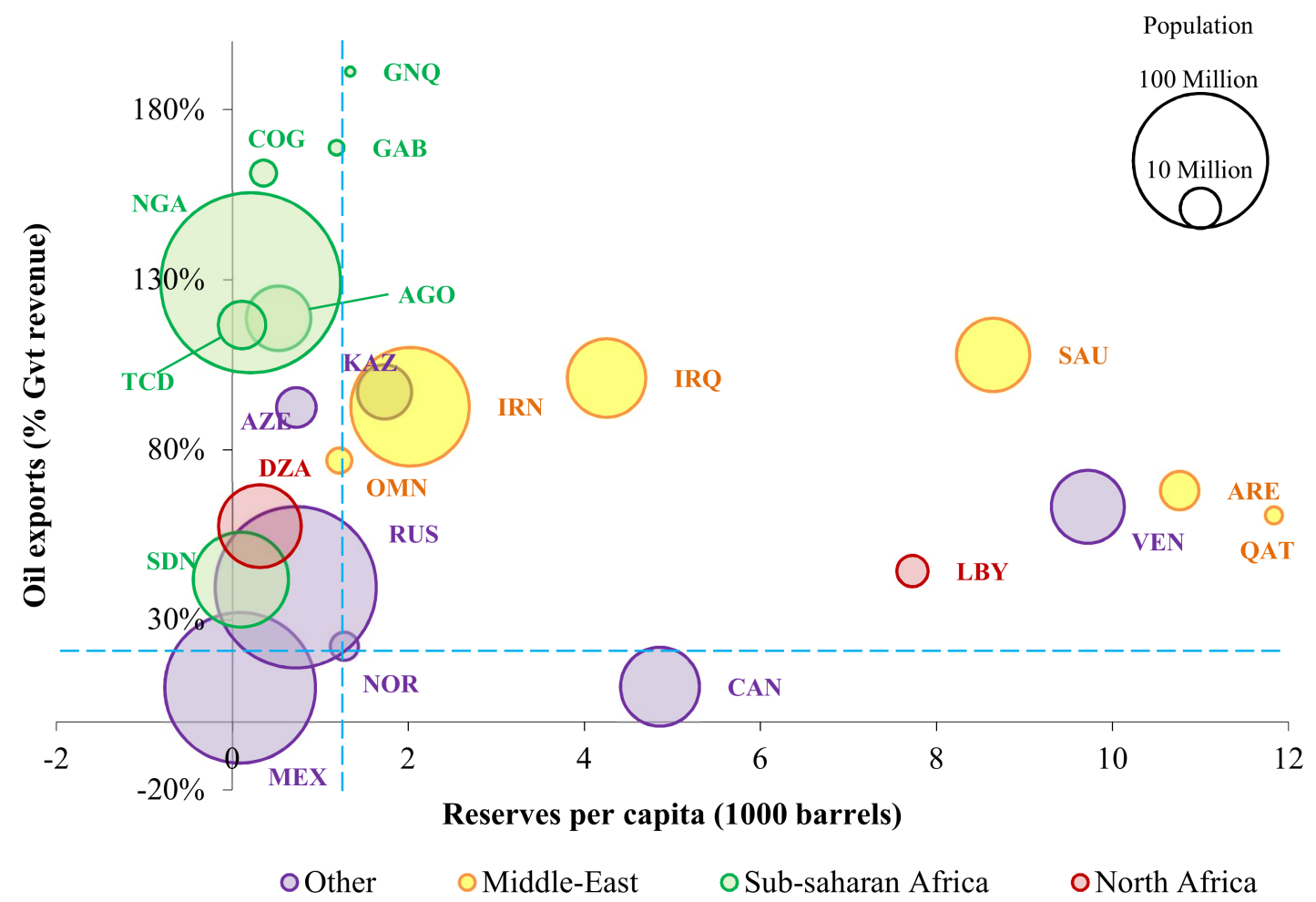

Figure 6. Exposure of state: oil exports vs. state budget (2014). Note: The dotted lines are centered on Norway (NOR). Data: $[19,21,25,26]$. Kuwait (KWT) is not shown because it has very high reserves per capita $(27,000 \mathrm{bl}$, oil exports $\sim 70 \%$ government revenue). 


\subsection{Macroeconomic Performance and Government Revenue}

Whereas the descriptive statistics in the previous section focus on one single point in time (mainly the year 2014), here we perform an econometric analysis spanning the period of 1990-2014 to provide insight into the impact of oil price fluctuations on macroeconomic performance (GDP) and government revenue in oil-exporting countries. Results (estimates for elasticity parameter $\beta$ ) are presented in Figures 7 and 8 and Table 3 for the following regression equation:

$$
\ln \left(\frac{Y_{t}}{\text { capt }_{t}}\right)=\alpha+\beta * \ln \left(\text { oil price }_{t}\right)+\gamma * \text { time trend }_{t}
$$

Two estimations are performed, in which the dependent variable $Y_{t}$ is either the GDP or the government revenue. An elasticity value of 1 implies that an $x \%$ change in oil price is matched by an $x \%$ change GDP per capita (or government revenue per capita). By expressing the dependent variable in per capita terms, we account for the size of the country. Furthermore, we do a trend-corrected estimation by including a variable that captures linear trends over time.

Table 3. Regression of GDP and government revenue (per capita) to oil price. Source: oil price is from BP (2015), oil exports are from BP (2015) and Enerdata (2016), GDP from World Bank (2016), government revenue from International Monetary Fund (IMF) (2015), and population from United Nations (UN) (2015).

\begin{tabular}{|c|c|c|c|c|c|c|}
\hline \multirow{2}{*}{ Country } & \multirow{2}{*}{ ISO3 Code } & \multirow{2}{*}{ Region } & \multicolumn{2}{|c|}{$\begin{array}{l}\text { GDP Per Capita } \\
\text { vs. Oil Price }\end{array}$} & \multicolumn{2}{|c|}{$\begin{array}{l}\text { Gvt Revenue Per } \\
\text { Capita vs. Oil Price }\end{array}$} \\
\hline & & & Elast. & $\mathbf{R}^{2}$ & Elast. & $\mathbf{R}^{2}$ \\
\hline Saudi Arabia & SAU & Middle-East & 0.5 & $97 \%$ & 0.9 & $98 \%$ \\
\hline United Arab Emirates & ARE & Middle-East & 0.2 & $84 \%$ & 0.3 & $45 \%$ \\
\hline Kuwait & KWT & Middle-East & 0.7 & $96 \%$ & 0.6 & $96 \%$ \\
\hline Iraq & IRQ & Middle-East & 0.8 & $98 \%$ & 1.1 & $98 \%$ \\
\hline Qatar & QAT & Middle-East & 0.4 & $99 \%$ & 0.6 & $98 \%$ \\
\hline Iran & IRN & Middle-East & 0.7 & $93 \%$ & 0.8 & $91 \%$ \\
\hline Oman & OMN & Middle-East & 0.5 & $98 \%$ & 0.6 & $98 \%$ \\
\hline Algeria & DZA & North Africa & 0.7 & $96 \%$ & 0.9 & $99 \%$ \\
\hline Libya & LBY & North Africa & 0.6 & $68 \%$ & 1 & $94 \%$ \\
\hline Nigeria & NGA & Sub-Saharan Africa & 0.4 & $98 \%$ & 0.8 & $85 \%$ \\
\hline Angola & AGO & Sub-Saharan Africa & 0.9 & $97 \%$ & 1.4 & $99 \%$ \\
\hline Equatorial Guinea & GNQ & Sub-Saharan Africa & 0.7 & $94 \%$ & 1.1 & $92 \%$ \\
\hline Republic of Congo & COG & Sub-Saharan Africa & 0.9 & $97 \%$ & 1.2 & $99 \%$ \\
\hline Gabon & GAB & Sub-Saharan Africa & 0.7 & $93 \%$ & 0.5 & $93 \%$ \\
\hline Sudan & SDN & Sub-Saharan Africa & 0.3 & $99 \%$ & 1 & $97 \%$ \\
\hline Chad & TCD & Sub-Saharan Africa & 0.8 & $92 \%$ & 1.4 & $96 \%$ \\
\hline Russia & RUS & Other: CIS & 0.7 & $96 \%$ & 0.8 & $96 \%$ \\
\hline Kazakhstan & KAZ & Other: CIS & 0.8 & $95 \%$ & 1 & $96 \%$ \\
\hline Azerbaijan & AZE & Other: CIS & 0.7 & $96 \%$ & 0.9 & $96 \%$ \\
\hline Venezuela & VEN & Other: Americas & 0.3 & $91 \%$ & 0.4 & $93 \%$ \\
\hline Canada & CAN & Other: Americas & 0.4 & $99 \%$ & 0.3 & $98 \%$ \\
\hline Mexico & MEX & Other: Americas & 0.1 & $88 \%$ & 0.2 & $95 \%$ \\
\hline Norway & NOR & Other: Europe & 0.3 & $98 \%$ & 0.3 & $98 \%$ \\
\hline \multicolumn{3}{|c|}{ Average of exporters } & 0.5 & $98 \%$ & 0.5 & $99 \%$ \\
\hline
\end{tabular}




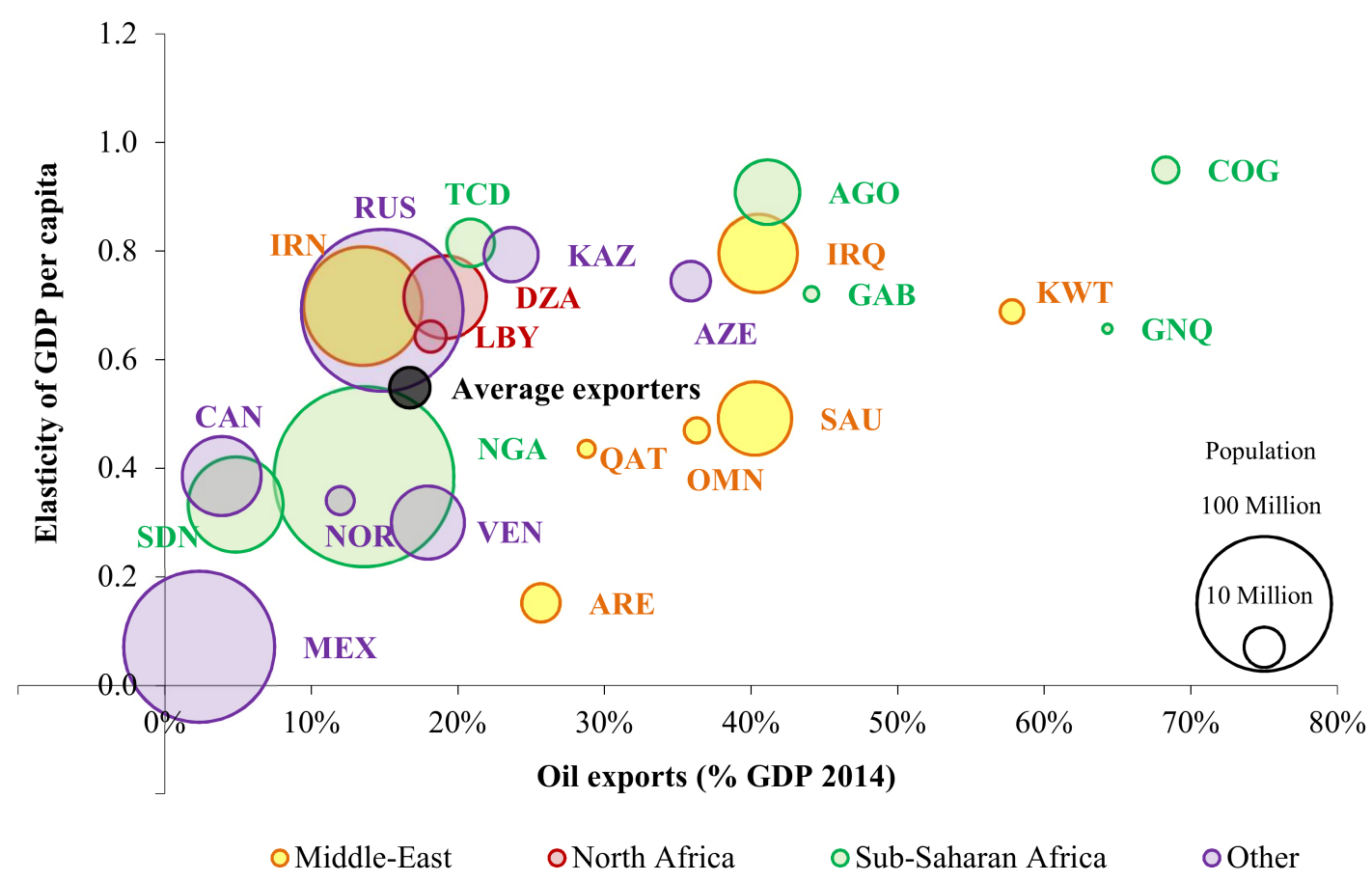

Figure 7. Elasticity of GDP per capita to oil price (1990-2014). Size of the bubbles indicates population size in 2014. GDP per capita and oil price are expressed in current USD. Data source: oil price [19], oil exports [19,20], GDP [25], and population [21].

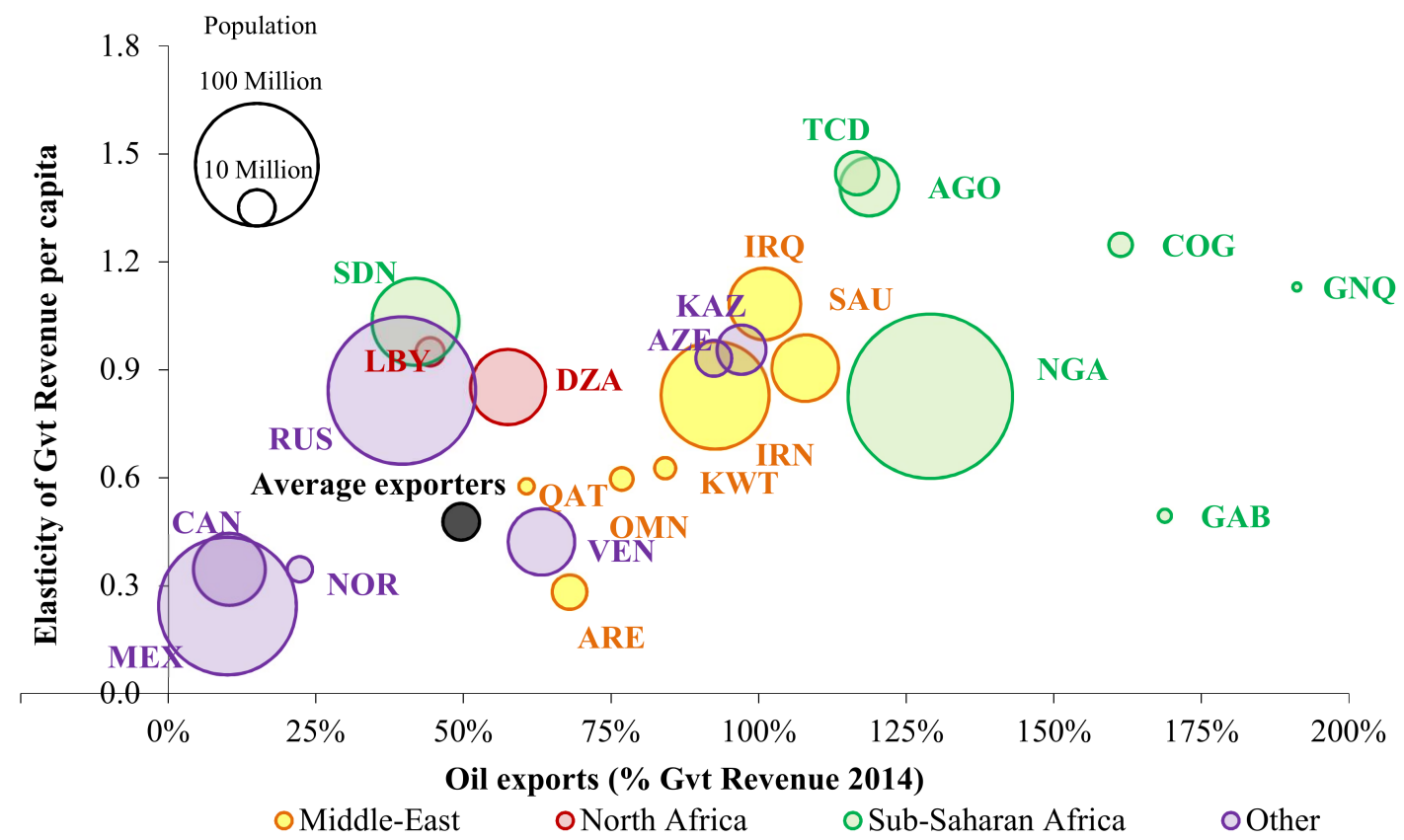

Figure 8. Elasticity of government (Gvt) revenue per capita to oil price (1990-2014). Size of the bubbles indicates population size in 2014. Government revenue per capita and oil price are expressed in current USD. Data sources: oil price: BP (2015), oil exports: BP (2015) and Enerdata (2016), government revenue: IMF (2015), population: UN (2015).

Both Figures 7 and 8 show that the elasticities of GDP and government revenue with respect to the oil price rise with the dependency on oil exports. The reactivity of GDP per capita to oil price, 
shown in Figure 7, appears high (above the average over all exporters of 0.55) for five Sub-Saharan African exporters, two North African exporters, and three Middle-Eastern countries including Iraq (IRQ) and Iran (IRN). For countries like Congo (COG) and Angola (AGO), the elasticity of the GDP per capita with respect to the oil price approaches 1, indicating strong comovements between macroeconomic performance and crude oil prices. The other Gulf Cooperation Council exporters (0.4-0.5), Nigeria (NGA, 0.4), and Sudan (SDN, 0.3) display a lower reactivity of GDP to oil price, in the order of magnitude of other exporters like Canada (CAN), Norway (NOR), and Venezuela (VEN) (all below 0.4). The low elasticity of the United Arab Emirates (ARE) may be explained by a more diversified economy, with Dubai developing its services sector beyond the oil and gas industry (see Figure 6 above and [27]). The low elasticity of Mexico may be explained by the comparably small value of oil exports compared to GDP, improving resilience to oil price shocks.

Government revenue can perhaps be considered as a better indicator than GDP in terms of short-term political stability, since it connects to the capacity of the state to deliver basic public needs such as health, infrastructure, or security. Although on average, the value of the elasticity of government revenue is comparable to that of GDP (due to relatively large government revenue in Mexico, Norway, and Canada), region-specific estimates show elasticity values that exceed unity for several countries, particularly in Sub-Saharan Africa (five countries), but also in Iraq. Furthermore, North African exporters and large Middle-Eastern countries also show a very high elasticity (above 0.8 ), suggesting substantial dependency of the state budget on oil price fluctuations. As an illustration, Angola (AGO, with an elasticity of government revenue above 1) has sent on April 6, 2016 [28], a formal letter to the International Monetary Fund (IMF) for support to deal with the impact of low oil price on the fiscal revenues of the state. Smaller Gulf Cooperation Council exporters and Gabon (GAB) show a lower ratio (around 0.6), which remains higher than for other exporters (Mexico, Venezuela, Canada, and Norway). As with GDP, the singular behavior of the United Arab Emirates (ARE) may be explained by its diversification towards a service economy, which helps in providing alternative revenues to its government-see Figure 6 on the share of oil-related sectors in the economy and other work [27] for a discussion on Dubai and the United Arab Emirates.

\section{Macroeconomic Impacts of a Drop in Oil Prices}

\subsection{Methods: Scenario Definition and Model Description}

This section presents the two scenarios analyzed in Section 3.2. The type of analysis presented here is based on a comparative static approach, which means that a scenario is compared to a baseline for a given year (2015), which differs from a projection or forecasting exercise. We study a low oil price scenario that is ceteris paribus in nature: the change in oil price is the only difference between the scenario and the baseline, such that the resulting macroeconomic impact can be uniquely attributed to the oil price shock and corresponding general equilibrium feedbacks. The "baseline" considers "business-as-usual" development, with oil prices remaining around 100 USD per barrel in 2015. The "60\% scenario" assumes an oil price of 40 USD per barrel in 2015, which is $60 \%$ lower as compared to the baseline in dollar terms.

The macroeconomic impacts of the oil price scenarios are analyzed with the JRC-GEM-E3 (General Equilibrium Model for Economy-Energy-Environment) model (for a recent application see [29]). It is a multiregion computable general equilibrium model that covers the interactions between the economy, the energy system, and the environment. JRC-GEM-E3 covers the entire economy and can be used to evaluate consistently the distributional effects of policies on the national accounts, investment, consumption, public finance, foreign trade, and employment for the various economic sectors and agents across the countries. The model includes all 28 member states of the European Union (EU) and all major non-European countries. The whole economy is represented in 21 economic sectors. The countries are linked through endogenous bilateral trade. The JRC-GEM-E3 results are of comparative static nature, and reflect the annual impact of imposing the lower oil price during a full 
year with the economy fully adapting to the new situation. In other words, the lagged impacts of oil price changes are observed to be spread over a couple of years, whereas in the JRC-GEM-E3 model they are assumed to happen immediately in the same year. Further, this methodology also assumes that the EU economy is in equilibrium. The model is calibrated using the GTAP 8 (Global Trade Analysis Project) database. The JRC-GEM-E3 model has been used to analyze the macro economic effects of the climate, energy, and air quality policies to support EU policymakers. Other applications [30-32] use earlier versions of the JRC-GEM-E3 model to simulate the impact of high oil prices (the latter focusing on the cross-relation with climate policies) and to analyze a number of scenarios of the 2012 Iran crisis and the boycott imposed by the Western world.

\subsection{Simulation Results: The Key Role of Oil Trade Dependence}

This section presents the macroeconomic impact of the $60 \%$ scenario with the JRC-GEM-E3 model. Both consumption and gross domestic product (GDP) are presented as a percentage difference from the baseline. The global consumption and GDP increases in the world are around 1\%. As expected, the economic impact on oil importing countries is positive, while oil exporting countries are negatively affected by lower oil prices.

Figures 9 and 10 and Tables 4 and 5 show that the economic impact on oil price drop is not uniform across countries. Consumption decline in oil exporting countries would range from $2.1 \%$ to $12.8 \%$. The fall in the price of oil results in a steep decline in consumption in Middle East countries, particularly Saudi Arabia. In Sub-Saharan Africa, a 60\% reduction in the price of oil would lead consumption to fall by $7.25 \%$. Given that Sub-Saharan Africa is analyzed as a whole, the impact on oil exporting countries is expected to be even higher. The effect on North African countries is lower than that on the rest of oil exporting countries (a 2.1\% contraction) due to their relatively low consumption level and their economic structure not excessively depending on oil exports. In general terms, consumption impact differences could be partly explained by the degree of economic dependence on oil. Figure 9 shows the relation between consumption variations and oil exports. Perhaps unsurprisingly, the effect of oil prices on consumption is strongly correlated with export dependence. Thereby, countries where the share of oil in total exports is very high are more vulnerable to lower oil prices. Although this is an important determinant for the results, a country's net trade position for crude oil is not the only factor influencing the macroeconomic impact shown here. The impact on GDP incorporates oil consumption in all sectors in the economy. Canada, although being a net exporter of crude oil, experiences a macroeconomic benefit from the drop in oil prices, which could be explained by the high rate of oil use per capita in the country, combined with a potential positive effect of increased global economic output on Canada's exports of goods and services.

Table 4. Impact of a $60 \%$ oil price drop on private consumption. Source: JRC-GEM-E3 model.

\begin{tabular}{clcr}
\hline Consumption & \multicolumn{1}{c}{$\%$} \\
\hline Change with Baseline, 2015 & \multicolumn{1}{c}{$\%$} & & \multicolumn{1}{c}{ \% } \\
\hline World & 0.96 & Mexico (MEX) & 0.95 \\
European Union (EU28) & 1.52 & Argentina & -2.14 \\
USA & 1.65 & North Africa (NOAF) & 1.82 \\
Russia (RUS) & -3.97 & New Zealand & -12.81 \\
Canada (CAN) & 1.30 & Saudi Arabia (SAU) & -3.68 \\
Japan & 1.36 & Iran (IRN) & 2.02 \\
Australia & 1.33 & South Africa (ZAF) & -6.32 \\
China (CHN) & 1.85 & Rest of Middle East (MIEA) & -7.25 \\
India (IND) & 2.59 & Sub-Saharan Africa (SSAF) & 0.87 \\
Indonesia & 2.88 & Rest of Central and S. America & -5.88 \\
Brazil & 2.05 & Central Asia and Caucasus & 2.58 \\
Republic of Korea & 2.61 & Southeast Asia & 3.02 \\
\hline Rest of Europe and Turkey & 0.57 & Rest of Asia and Pacific &
\end{tabular}


Table 5. Impact of a 60\% oil price drop on real GDP. Source: JRC-GEM-E3 model.

\begin{tabular}{clcr}
\hline Value of GDP & \multicolumn{1}{c}{$\%$} \\
\hline Change with Baseline, 2015 & $\%$ & & \multicolumn{1}{c}{ \% } \\
\hline World & 1.11 & Mexico (MEX) & 1.16 \\
European Union (EU28) & 1.92 & Argentina & -2.79 \\
USA & 1.79 & North Africa (NOAF) & 2.42 \\
Russia (RUS) & -4.43 & New Zealand & -14.34 \\
Canada (CAN) & 1.67 & Saudi Arabia (SAU) & -5.21 \\
Japan & 1.56 & Iran (IRN) & 2.45 \\
Australia & 1.60 & South Africa & -8.58 \\
China (CHN) & 1.73 & Rest of Middle East (MIEA) & -8.56 \\
India (IND) & 3.21 & Sub-Saharan Africa (SSAF) & 0.90 \\
Indonesia & 3.24 & Rest of Central and S. America & -15.20 \\
Brazil & 2.65 & Central Asia and Caucasus & 2.95 \\
Republic of Korea & 3.25 & Southeast Asia & 3.32 \\
Rest of Europe and Turkey & 0.48 & Rest of Asia and Pacific &
\end{tabular}

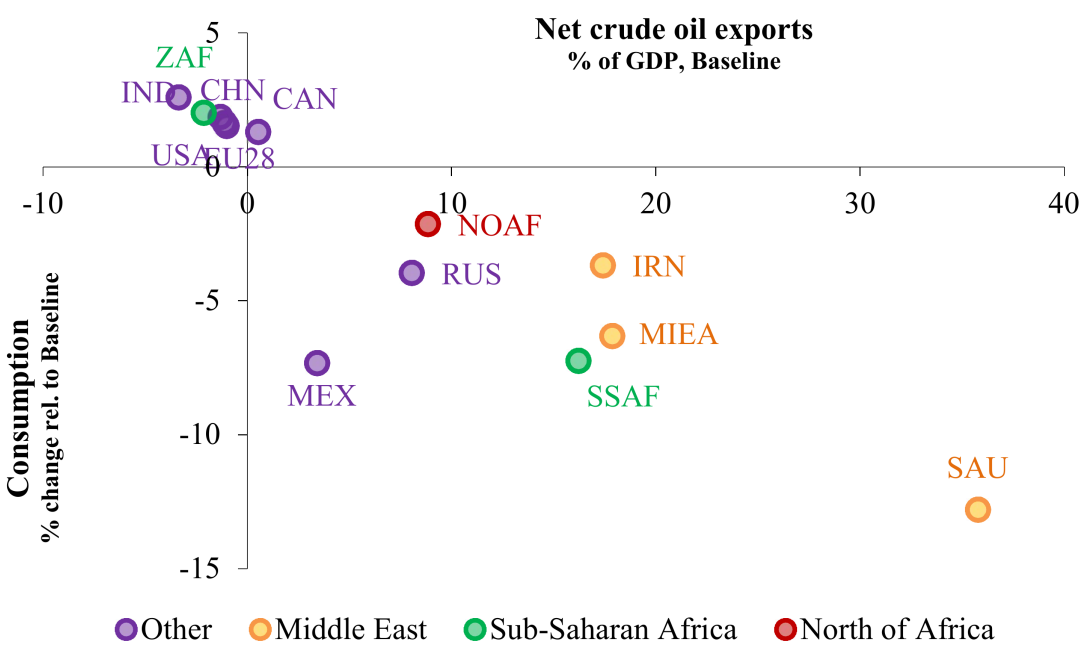

Figure 9. The impact of the low oil price on consumption vs. export dependence. Source: JRC-GEM-E3 model. Abbreviations: 28 Member States of the European Union (EU28), North Africa (NOAF), Sub-Sahara Africa (SSAF), Rest of Middle East (MIEA).

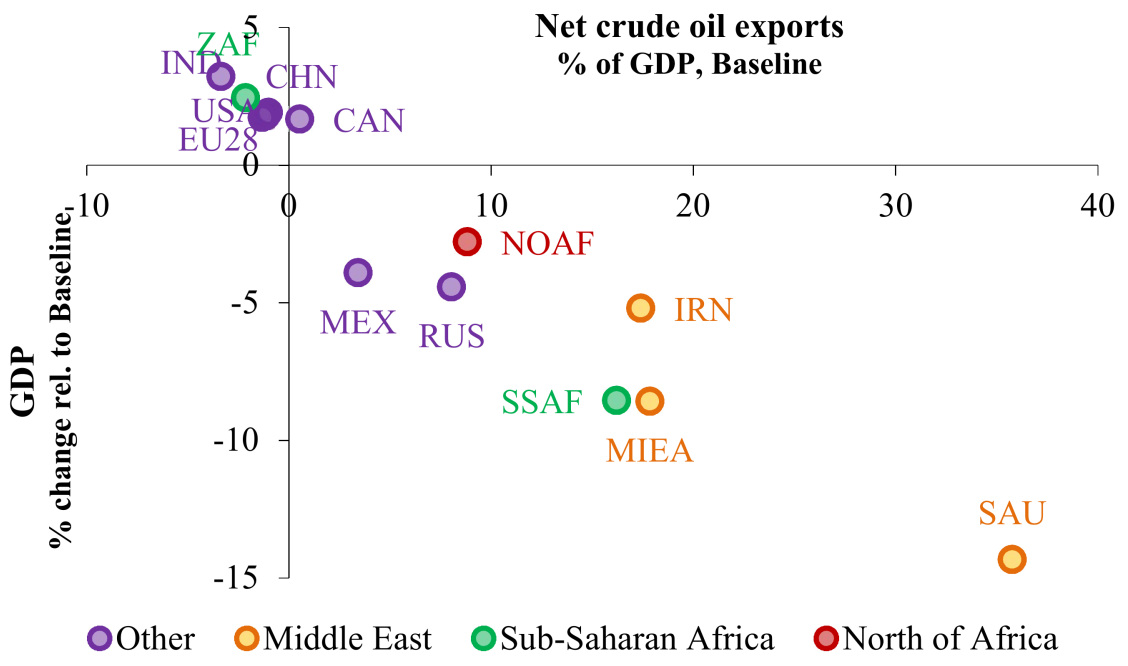

Figure 10. The impact of the low oil price on GDP vs. export dependence. Source: JRC-GEM-E3 model. 
Similarly, Figure 10 shows that the sharp decline in oil prices affects the GDP of oil exporting countries in a heterogeneous manner. A $60 \%$ reduction in the price of oil results in a $15.2 \%$ decline of the GDP in Central Asia and Caucasus, while the GDP of North Africa would decline by $2.8 \%$. The GDP of Middle East and Sub-Saharan African countries would decline by around $8.5 \%$. The impact of the low oil price on GDP is strongly correlated with import dependence (Figure 10). For instance, in Saudi Arabia where crude oil exports represent 35\% of the GDP, a $60 \%$ fall in the price of oil leads GDP to decline by $14.3 \%$. On the other hand, Mexican crude oil exports represent $3.4 \%$ of the GDP and therefore, the decline of the GDP would be substantially lower (3.9\%).

\section{Discussion}

Between mid-2014 and March 2016, the price of crude oil fell around 65\%, likely caused by a combination of drivers: (i) the U.S. tight oil evolution pushing up production levels, and the OPEC's (Organization of the Petroleum Exporting Countries) lack of intention to stabilize prices; (ii) an unanticipated slowdown of economic growth in Asia; (iii) supply and demand dynamics resulting in rising levels of oil stocks; and (iv) the increase in the value of the U.S. dollar compared to other currencies, making crude oil more costly for other countries. Low and volatile oil prices pose challenges for regions with a strong economic reliance on oil production. This paper combines an econometric analysis with a model-based assessment to explore the relation between macroeconomic outcomes and oil price fluctuations in regions that are net exporters of crude oil.

Firstly, estimates reveal the strong connection between oil prices and GDP (and government revenue) over the period of 1990-2014 in several oil-exporting regions. Several Sub-Saharan African exporters, in particular, show a vulnerable position that combines a relatively strong economic dependence on oil prices, limited buffer capacity through sovereign wealth funds, low oil reserves per capita, and comparably low indicators for political stability or human development. Adding high projections of population growth, the economic and political stability in Nigeria could be susceptible to oil market disruptions. North African producers Algeria and Libya share several of these characteristics, rendering the countries vulnerable to a lasting period of low oil price, particularly in the light of ongoing conflicts in the region. Many countries in the Middle East strongly depend on oil production, but appear less vulnerable to low oil prices because of low marginal production costs, the presence of a SWF, and relatively high reserves per capita. The United Arab Emirates appears less sensitive to the oil price, due to economic and fiscal diversification, a large SWF, and a relatively high political stability.

Secondly, the economy-wide impact of a $60 \%$ reduction of the oil price is analyzed with the JRC-GEM-E3 model, contributing to the literature on oil price shocks and macroeconomic performance $[33,34]$. This model-based assessment complements the historical analysis by comparing a situation with and without the drop in oil prices, thereby isolating the price shock from other events that may occur in the same time horizon in a real-world setting. The results show that an oil price drop can have substantial effects on oil-exporting countries, with regional impact differentiation strongly correlated with import or export dependence. While crude oil importers experience relatively small benefits from lower prices, countries with a high share of oil in total exports appear economically vulnerable to short-run oil price decreases, with simulated GDP decreases ranging between $2 \%$ and $13 \%$.

Although the macroeconomic analysis does not account for the potential use of SWFs, results (Section 3.2) suggest lower elasticities of GDP to changes in the crude oil price compared to the backward-looking regression analysis (Section 2.2). Apart from differences in regional aggregation, the macroeconomic modelling assessment excludes price shocks of other commodities, while the econometric analysis did not control for the economic impact of other commodities or natural resources. This could be explored in further research, incorporating a fully-fledged econometric analysis and addressing endogeneity issues that arise because of the two-way influence between oil price and GDP. Importantly, the Computable General Equilibrium (CGE) model allows for adjustment mechanisms such as endogenous price changes, full capital and labor mobility across sectors, and shifting trade patterns in response to changes in relative prices. In a real-world setting, 
there may be rigidities that prevent adjustments in the short run that are not covered by the model. Hence, while both methodologies contribute valuable insights and derive a common pattern relating economic dependency on oil exports and vulnerability to oil price shocks, the quantification may lie in the middle of both estimates.

More broadly, the analyses presented here connect to the literature on the natural resource curse [35-38] that posits that regions with a high endowment of natural resources, such as oil, experience lower economic growth rates in the long run. Institutions are a key underlying factor for the theorem [39,40], but also the importance of (price) volatility has been revealed as a crucial feature by earlier work [41]. Literature shows [42] that long-run economic effects of commodity price booms may run counter to short-run responses to price shocks. The model-based assessment presented in this paper does not include long-run effects, but future modeling work could consider these dynamics in relation to wealth accumulation and investment expenditure of oil rents [43].

A related strand of literature studies the connection between commodity prices and political instability and conflict. The evidence on commodity price movements and the outbreak and intensity of conflict is mixed [44-48], and different theoretical views have been put forward to explain the empirical results. On one hand, higher commodity prices may improve economic opportunities, and therefore make crime and rebellion less attractive options. On the other hand, high resource rents may raise the expected pay-off of (potentially violent) attempts to seize ownership of natural resources, which could imply a positive relationship between commodity prices and conflicts. The analysis we present here does not aim to provide claims about the causality of conflicts in resource-rich countries. Figure 11 does, however, suggest an increasing trend between our estimates of the elasticity of GDP to the oil price and battle-related deaths over the period of 1990-2014, hinting that economic exposure to oil price fluctuations could relate to violent conflict in this subset of countries. A detailed analysis of the underlying mechanisms is beyond the scope of this paper, but the positive correlation displayed in Figure 11 is in line with earlier evidence that relates natural resource endowment and state fragility [49]. The impact of conflicts does not stop at jurisdictional borders, as highlighted by the recent European migrant crisis. Migration flows into neighboring countries, but also historical ties play a role in determining migration patterns (e.g., France-Algeria and Portugal-Angola; see Figures A1 and A2 in Appendix A).

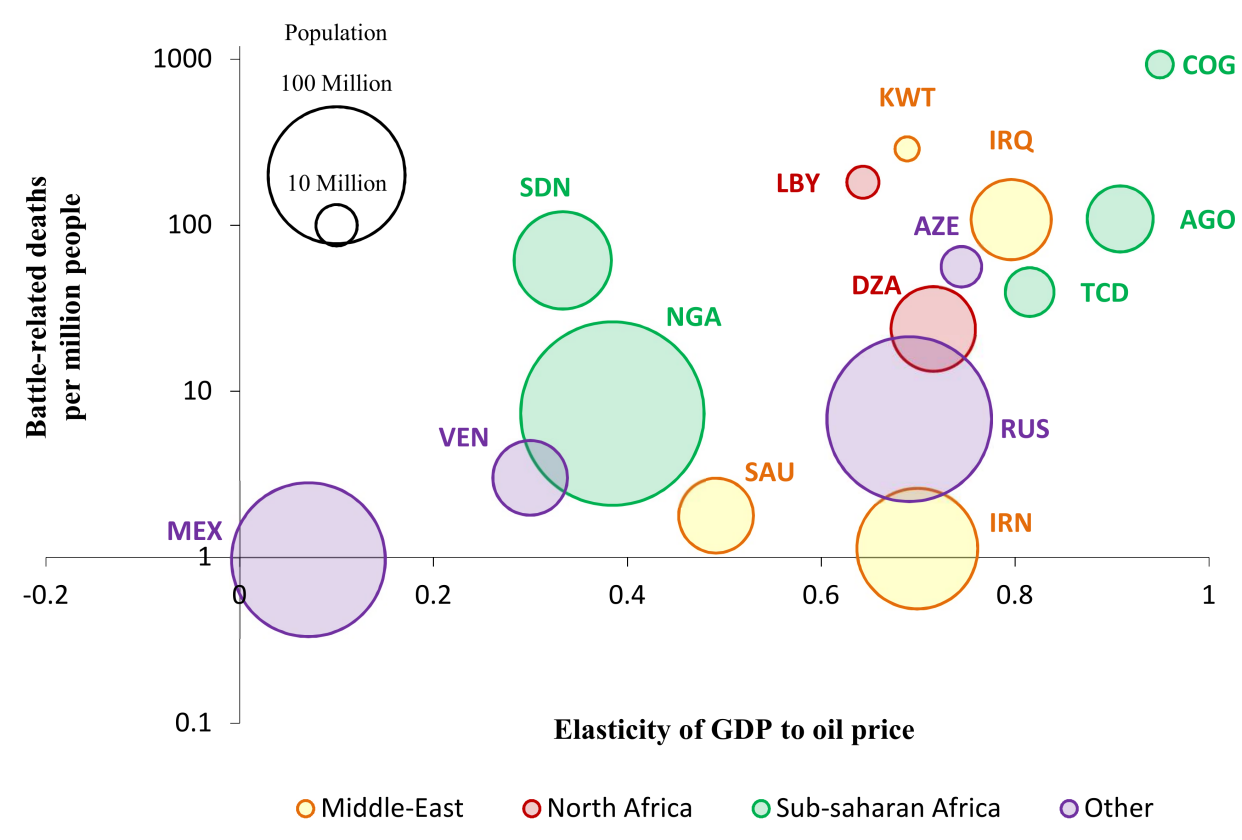

Figure 11. Relation between the exposure of macroeconomic performance to the oil price and battle-related deaths per million people (1990-2014). Size of the bubbles indicates population size in 2014. Data source: own estimates and [25]. 
Finally, the key question is what an appropriate policy response to oil market volatility entails. Policies that reduce the exposure to oil price fluctuations can include the establishment of a SWF; fiscal and monetary policy [50]; the distribution of resource rents [51]; a well-considered spending of rents, for example, on education [52]; and an economic and energy-related diversification strategy. If a global shift away from fossil fuels in the context of ambitious global climate policies implied by the Paris Agreement is to bring low oil prices for a sustained period, challenges lie ahead to reconcile a low-carbon pathway (Sustainable Development Goal 13: Climate Action) with an inclusive growth story (Sustainable Development Goal 1: No Poverty) in which also oil-producing regions prosper. By illustrating the sensitivity of already vulnerable states to oil price fluctuations, this paper highlights the gains from political action that steers economies away from the reliance on oil production towards a more sustainable growth path.

Acknowledgments: This paper is based on earlier work presented in a JRC Science for Policy Report [53], which has benefitted from the comments of our colleagues at DG ENER and DG JRC.

Author Contributions: Alban Kitous and Kimon Keramidas performed econometric analysis; Toon Vandyck did macroeconomic assessment; Alban Kitous, Kimon Keramidas, and Toon Vandyck wrote the paper; Luis Rey Los Santos and Krzysztof Wojtowicz analyzed data; Bert Saveyn contributed to the writing and analysis.

Conflicts of Interest: The authors declare no conflict of interest.

Disclaimer: The views expressed are purely those of the authors and may not in any circumstances be regarded as stating an official position of the European Commission.

\section{Appendix A}

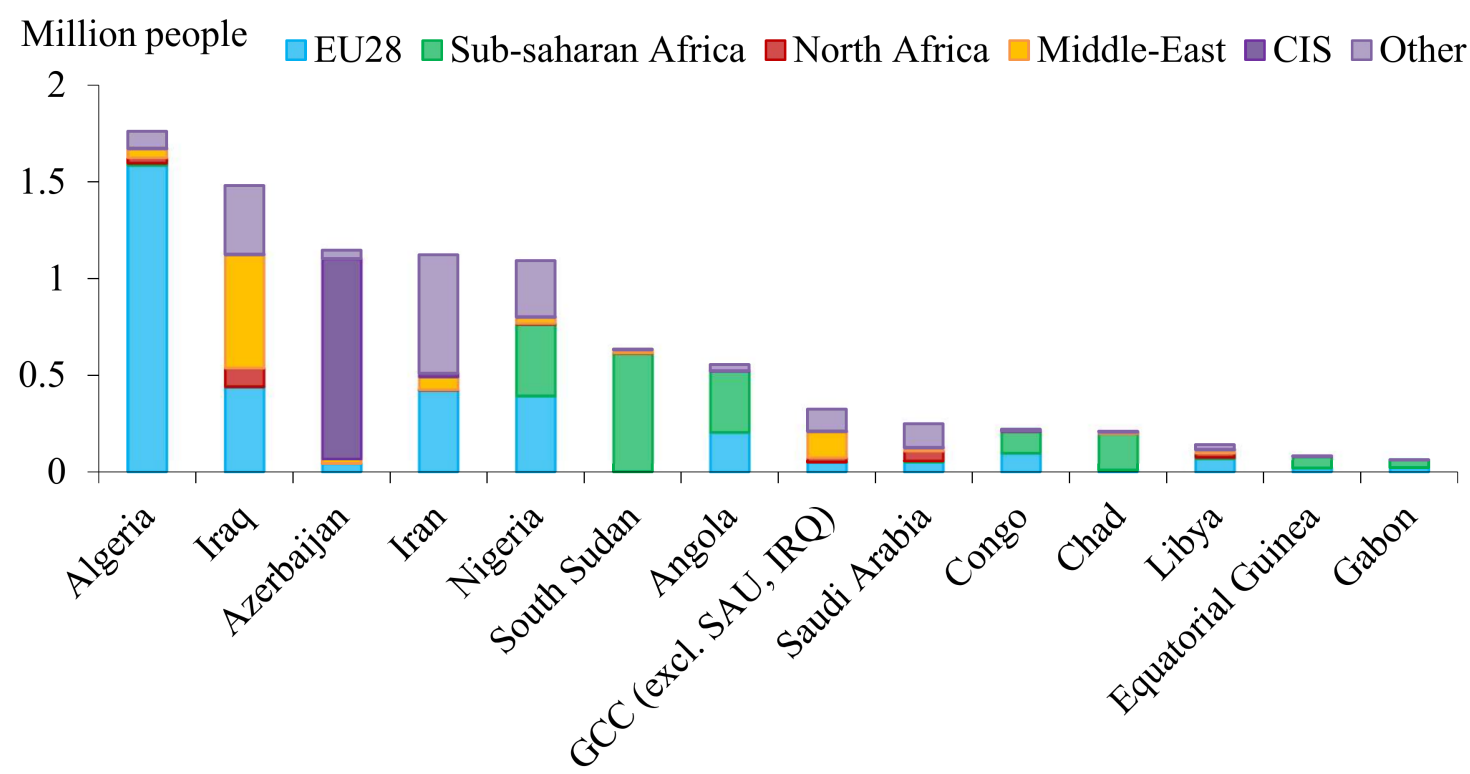

Figure A1. Foreign residents (in millions) originating from oil-exporting countries (mid-2015). Note: The figures are the foreign residents and do not picture migration flows in a certain time period. They do not (fully) account for second- or later generation immigrants which (also) hold the nationality of the destination country. Data source: [54]. Abbreviations: The Gulf Cooperation Council (GCC) includes Bahrain, Kuwait, Oman, Qatar, the United Arab Emirates and Saudi Arabia (which is shown separately here). 


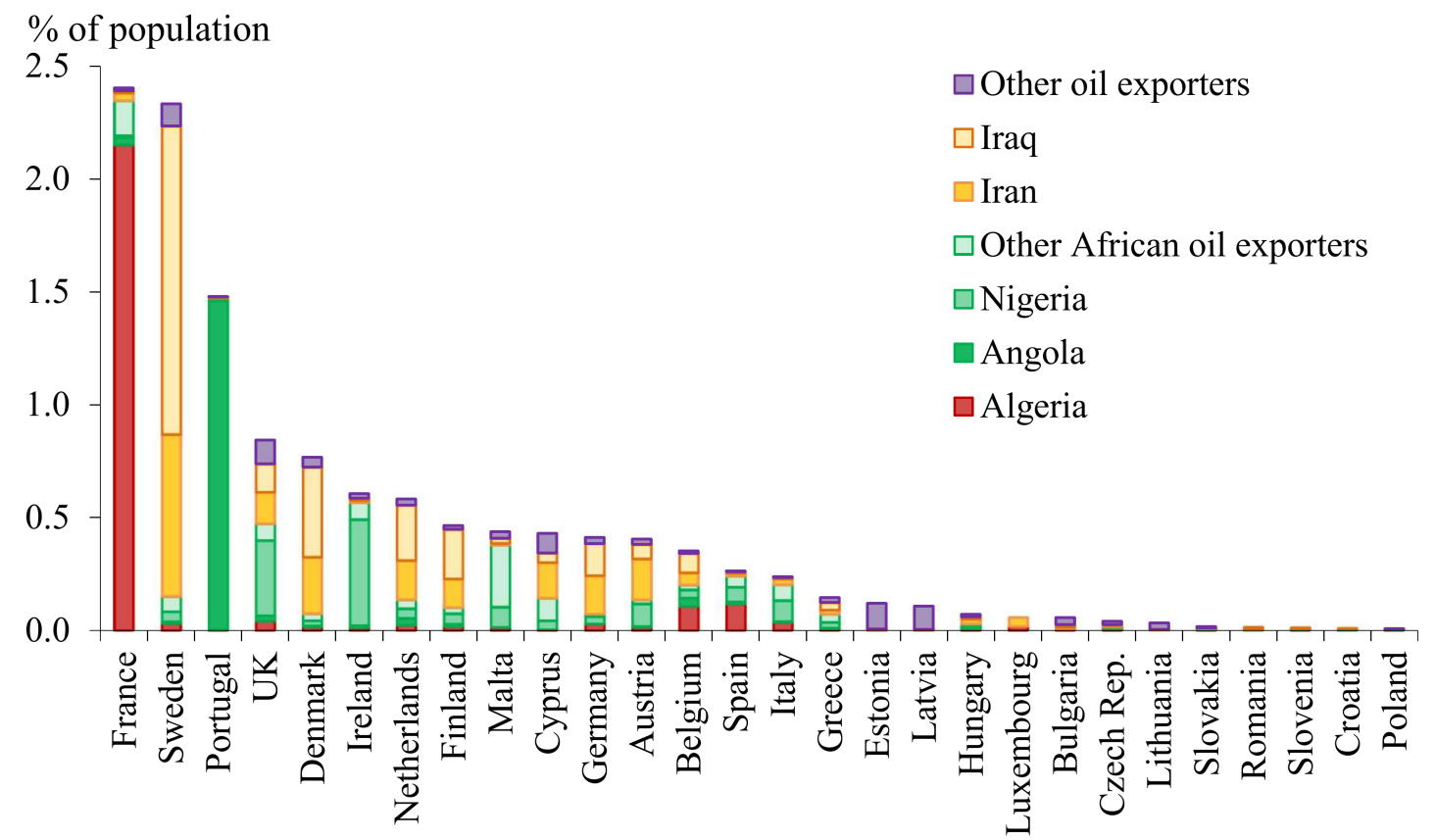

Figure A2. Origin of foreign residents in the EU28 (mid-2015). Data source: [54].

\section{References}

1. US Energy Information Administration. Available online: http://www.eia.gov/dnav/pet/pet_pri_spt_s1_ d.htm (accessed on 23 March 2016).

2. Jacks, D.S. From Boom to Bust: A Typology of Real Commodity Prices in the Long Run; NBER Working Paper, No. w18874; National Bureau of Economic Research: Cambridge, MA, USA, March 2013.

3. Arezki, R.; Blanchard, O. Seven Questions about the Recent Oil Price Slump (22/12/2014). IMF Blog Post. Available online: https:/ /blogs.imf.org/2014/12/22/seven-questions-about-the-recent-oil-price-slump/ (accessed on 18 March 2016).

4. Baffes, J.; Kose, M.A.; Ohnsorge, F.; Stocker, M. The Great Plunge in Oil Prices: Causes, Consequences, and Policy Response; CAMA Working Paper 23/2015; The World Bank Group: Washington, DC, USA, June 2015.

5. Baumeister, C.; Kilian, L. Understanding the Decline in the Price of Oil since June 2014. J. Assoc. Environ. Resour. Econ. 2016, 3, 3131-3158. [CrossRef]

6. Husain, A.M.; Arezki, R.; Breuer, P.; Haksar, V.; Helbling, T.; Medas, P.A.; Sommer, M. Global Implications of Lower Oil Prices; IMF Staff Discussion Note. SDN/15/15; International Monetary Fund: Washington, DC, USA, 2015.

7. Pflüger, F. Oil Price Decline: No Room For Conspirators (26/01/2015). Energy Post. 2015. Available online: http:/ / energypost.eu/ oil-price-decline-room-conspirators / (accessed on 24 March 2016).

8. Kleinberg, R.L.; Paltsev, S.; Ebinger, C.K.E.; Hobbs, D.A.; Boersma, T. Tight Oil Market Dynamics: Benchmarks, Breakeven Points, and Inelasticities. Energy Econ. 2017, 70, 70-83. [CrossRef]

9. IEA. Oil Market Report for March 2016; IEA: Paris, France, 2016.

10. DOE. (US Department of Energy). Fact \#918: March 28, 2016 Global Plug-in Light Vehicle Sales Increased by About 80\% in 2015. 2016. Available online: https:/ /www.energy.gov/eere/vehicles/fact-918-march-282016-global-plug-light-vehicle-sales-increased-about-80-2015 (accessed on 6 April 2016).

11. OICA (Organisation Internationale des Constructeurs d'Automobiles). 2005-2015 Sales Statistics. 2016. Available online: http:/ / www.oica.net/category/sales-statistics/ (accessed on 6 April 2016).

12. BP. Outlook to 2035. In BP Energy Outlook, 2016 ed.; British Petroleum: London, UK, 2016.

13. Kitous, A.; Keramidas, K.; Vandyck, T.; Saveyn, B.; Van Dingenen, R.; Spadaro, J.; Holland, M. Global Energy and Climate Outlook 2017: How Climate Policies Improve Air Quality (No. JRC107944); Joint Research Centre (Seville site): Sevilla, Spain, 2017. 
14. Levi, M. Five Things I Learned About the Oil Price Crash (24/02/2015). Energy, Security and Climate Blog. Council on Foreign Relations. 2015. Available online: https://www.cfr.org/blog/five-things-i-learnedabout-oil-price-crash\#more-5576 (accessed on 24 March 2016).

15. EIA. Short-Term Energy Outlook (STEO). March 2016; U.S. Energy Information Administration: Washington, DC, USA, 2016.

16. IEA. World Energy Outlook 2015; International Energy Agency: Paris, France, 2015.

17. EIA. The Annual Energy Outlook 2015 with Projections to 2040; US Energy Information Administration: Washington, DC, USA, 2015.

18. Knoema. Marginal Production Cost by Country 2014. 2016. Available online: http://knoema.com/vyronoe/ cost-of-oil-production-by-country / (accessed on 23 March 2016).

19. BP. BP Statistical Report 2015. 2015. Available online: https://www.bp.com/en/global/corporate/energyeconomics/statistical-review-of-world-energy.html (accessed on 23 March 2016).

20. Enerdata. Global Energy Database. 2016. Available online: http://globaldata.enerdata.net/database/ (accessed on 23 March 2016).

21. UN. United Nations Population Division. World Population Prospects: The 2015 Revision. 2015. Available online: http:/ / esa.un.org/unpd/wpp/Download/Standard/Population/ (accessed on 23 March 2016).

22. WB. Worldwide Governance Indicators. 2016. Available online: http:/ /info.worldbank.org/governance/ wgi/ (accessed on 23 March 2016).

23. UNDP. United Nations Development Program. Human Development Report 2015, Work for Human Development. Table 1. 2015; p. 208. Available online: http://hdr.undp.org/en/content/human-developmentreport-2015-work-human-development (accessed on 23 March 2016).

24. Wikipedia. Available online: http://en.wikipedia.org/wiki/Sovereign_wealth_fund (accessed on 23 March 2016).

25. World Bank. World Development Indicators. 2015. Available online: http://databank.worldbank.org/data/ reports.aspx?source=world-development-indicators (accessed on 23 March 2016).

26. IMF. World Economic Outlook-Adjusting to Lower Commodity Prices. October 2015. Available online: https:/ / www.imf.org/external/pubs/ft/weo/2015/02/weodata/index.aspx (accessed on 23 March 2016).

27. International Monetary Fund. Economic Diversification in the GCC: Past, Present, and Future; IMF Staff Discussion Note, SDN/14/12; International Monetary Fund: Washington, DC, USA, December 2014.

28. IMF. Statement by IMF Deputy Managing Director Min Zhu on Angola (6 April 2016). Available online: http:/ / www.imf.org/external/np/sec/pr/2016/pr16155.htm (accessed on 8 April 2016).

29. Vandyck, T.; Keramidas, K.; Saveyn, B.; Kitous, A.; Vrontisi, Z. A global stocktake of the Paris pledges: Implications for energy systems and economy. Glob. Environ. Chang. 2016, 41, 46-63. [CrossRef]

30. Ciscar, J.C.; Russ, P.; Paroussos, L.; Stroblos, N. Vulnerability of the EU Economy to Oil Shocks: A General equilibrium Analysis with the GEM-E3 Model. In Proceedings of the 13th Annual Conference of the European Association of Environmental and Resource Economics, Budapest, Hungary, 25-28 June 2004.

31. Maisonnave, H.; Pycroft, J.; Saveyn, B.; Ciscar, M.J. Does climate policy make the EU economy more resilient to oil price rises? A CGE analysis. Energy Policy 2012, 47, 172-179. [CrossRef]

32. Kitous, A.; Saveyn, B.; Gervais, S.; Wiesenthal, T.; Soria, A. Analysis of the Iran Oil Embargo; JRC Scientific and Technical Reports EUR 25691 EN; Publications Office of the European Union: Luxembourg, 2013.

33. Berument, M.H.; Ceylan, N.B.; Dogan, N. The impact of oil price shocks on the economic growth of selected MENA countries. Energy J. 2010, 149-176. [CrossRef]

34. Ghalayini, L. The Interaction between Oil Price and Economic Growth. Middle East. Finance Econ. 2011, 13, 127-141.

35. Sachs, J.D.; Warner, A.M. Natural Resource Abundance and Economic Growth (No. w5398); National Bureau of Economic Research: Cambridge, MA, USA, 1995.

36. Sachs, J.D.; Warner, A.M. The curse of natural resources. Eur. Econ. Rev. 2001, 45, 827-838. [CrossRef]

37. Frankel, J.A. The Natural Resource Curse: A Survey (No. w15836); National Bureau of Economic Research: Cambridge, MA, USA, 2010.

38. Haber, S.S.; Menaldo, V. Do Natural Resources Fuel Authoritarianism? A Reappraisal of the Resource Curse. Am. Political Sci. Rev. 2011, 105, 1-26. [CrossRef]

39. Brunnschweiler, C.N. Cursing the blessings? Natural resource abundance, institutions, and economic growth. World Dev. 2008, 36, 399-419. [CrossRef] 
40. Robinson, J.A.; Torvik, R.; Verdier, T. Political foundations of the resource curse. J. Dev. Econ. 2006, 79, 447-468. [CrossRef]

41. Van der Ploeg, F.; Poelhekke, S. Volatility and the natural resource curse. Oxf. Econ. Pap. 2009, 61, 727-760. [CrossRef]

42. Collier, P.; Goderis, B. Commodity Prices, Growth, and the Natural Resource Curse: Reconciling a Conundrum. 2008. Available online: https:/ /ssrn.com/abstract=1473716 (accessed on 23 March 2016).

43. Blum, M.; Ducoing, C.; McLaughlin, E. A Sustainable Century? Genuine Savings in Developing and Developed Countries, 1900-2000. In National Wealth What Is Missing, Why It Matters; Hamilton, K., Hepburn, C., Eds.; Oxford University Press: Oxford, UK, 2017.

44. Bazzi, S.; Blattman, C. Economic shocks and conflict: Evidence from commodity prices. Am. Econ. J. Macroecon. 2014, 6, 1-38. [CrossRef]

45. Brückner, M.; Ciccone, A. International commodity prices, growth and the outbreak of civil war in Sub-Saharan Africa. Econ. J. 2010, 120, 519-534. [CrossRef]

46. Besley, T.J.; Persson, T. The Incidence of Civil War: Theory and Evidence (No. w14585); National Bureau of Economic Research: Cambridge, MA, USA, 2008.

47. Collier, P.; Hoeffler, A.; Söderbom, M. On the duration of civil war. J. Peace Res. 2004, 41, 253-273. [CrossRef]

48. Collier, P.; Hoeffler, A. On economic causes of civil war. Oxf. Econ. Pap. 1998, 50, 563-573. [CrossRef]

49. Collier, P.; Venables, A.J. Natural Resources and State Fragility; Robert Schuman Centre for Advanced Studies (RSCAS) working paper; RSCAS: Firenze, Italy, April 2010.

50. Céspedes, L.F.; Velasco, A. Macroeconomic performance during commodity price booms and busts. IMF Econ. Rev. 2012, 60, 570-599. [CrossRef]

51. Sala-i-Martin, X.; Subramanian, A. Addressing the natural resource curse: An illustration from Nigeria. In Economic Policy Options for a Prosperous Nigeria; Palgrave Macmillan: London, UK, 2008; pp. 61-92.

52. Deaton, A. Commodity prices and growth in Africa. J. Econ. Perspect. 1999, 13, 23-40. [CrossRef]

53. Kitous, A.; Saveyn, B.; Keramidas, K.; Vandyck, T.; Santos, R.L.; Wojtowicz, K. Impact of Low Oil Prices on Oil Exporting Countries; JRC Science Policy Report; Publications Office of the European Union: Luxembourg, 2016.

54. UN. United Nations Population Division. Trends in International Migrant Stock: Migrants by Destination and Origin; United Nations: New York, NY, USA, 2015. 